\title{
Pseudotumor Hemofilia, Suatu Komplikasi Hemofilia yang Jarang
}

\section{Pseudotumor Haemophilia, a Rare Complication of Haemophilia}

\author{
Ade Nurshanty, Djoko Heri H \\ Laboratorium IImu Penyakit Dalam Rumah Sakit Umum Daerah Dr. Saiful Anwar Malang
}

\begin{abstract}
ABSTRAK
Pseudotumor adalah kista berisi darah pada jaringan lunak atau tulang. Satu sampai dua persen hemofilia berat menyebabkan pseudotumor, yang bisa berasal dari jaringan lunak atau pada subperiosteal atau area intraosseus. Pseudotumor jarang terjadi namun merupakan komplikasi hemofilia yang berbahaya. Kami laporkan kasus pseudotumor hemofilia pada seorang laki-laki 27 tahun dengan keluhan bengkak pada paha kanan yang muncul tiba-tiba, merata dari pangkal paha sampai lutut. Keluhan hilang timbul, bergantian pada kaki kanan kiri sejak 2002. Riwayat perdarahan yang sulit berhenti 15 tahun sebelumnya. Pemeriksaan MRI (magnetic resonansi imaging) menunjukkan massa intra muskular regio femur dekstra $1 / 3$ proksimal hingga 1/3 tengah dan massa intra muskular regio femur sinistra 1/3 proksimal melibatkan kompartemen anterior dan bone marrow replacement. Didapatkan Hemofilia A sedang dengan APTT memanjang (faktor VIII 7\%) pada pemeriksaan darah. Pasien membaik dengan terapi konservatif, yaitu pemberian faktor VIII.
\end{abstract}

Kata Kunci: Hemofilia A, pseudotumor hemofilia

\section{ABSTRACT}

Pseudotumor is a blood-filled cysts in soft tissue or bone. One until two percent of severe hemophilia cause pseudotumor, which can come from soft tissue or subperiosteal or intraosseus area. Pseudotumor is a rare but dangerous complication of hemophilia. We report a case of pseudotumor hemophilia in males 27 years with complaints of swelling in his right thigh that appeared suddenly, uneven from the groin to the knee. Complaints intermittent, alternating the left and right leg since 2002. The history of bleeding that is difficult to stop the previous 15 years. MRI showed a mass intramuscular proximal region of the femur dekstra $1 / 3$ to $1 / 3$ central and intra muscular mass region of the proximal third of the left femur involving the anterior compartment and bone marrow replacement. Hemophilia $A$ is obtained with the APTT being elongated (factor VIII 7\%) in blood tests. Patients improved with conservative therapy administration of factor VIII.

Keywords: Hemophilia A, pseudotumor hemophilia

Korespondensi: Ade Nurshanty. Laboratorium Ilmu Penyakit Dalam Rumah Sakit Umum Daerah Dr. Saiful Anwar Malang, Jl. Jaksa Agung Suprapto No. 2 Malang Tel.(0341)362101Email:ade_nurshanty@yahoo.com 


\section{PENDAHULUAN}

Hemofilia merupakan defek koagulasi yang disebabkan oleh fungsional atau kekurangan faktor pembekuan absolut. Kekurangan faktor (f) VIII (antihemophilic factor) menyebabkan hemophilia A (classic hemophilia); kekurangan faktor IX (komponen protrombin plasma) menyebabkan hemophilia B (Christmas disease). Kedua kelainan ini merupakan $x$-linked recessive, dan primer menyerang laki-laki, tapi ditransmisikan oleh wanita (1). Dokter selalu harus mencurigai kemungkinan adanya hemofilia A pada anak laki-laki yang disertai perdarahan abnormal disamping kemungkinan hemofilia B karena defisiensi faktor IX memang lebih jarang ditemukan. Hemofilia A, terjadi pada 1 dari 10.000 kelahiran laki-laki. Hemofilia A terjadi pada seluruh kelompok etnik di dunia $(2,3)$. Defisiensi baik faktor VIII maupun faktor IX menyebabkan tidak adanya komplek fungsional faktor intrinsik sehingga mengurangi pembentukan thrombin dan ketidakmampuan membentuk dan stabilisasi klot (4). Hemofilia A dihasilkan saat mutasi terjadi pada gen faktor VIII yang berada pada rantai panjang kromosom $x(x-q 28)$. Hemofilia A dapat menghasilkan berbagai macam perubahan, termasuk pengaturan ulang dari gen, mutasi yang salah, perubahan asam amino dalam molekul, kehilangan seluruh atau sebagian gen, dan insersi elemen genetik (2).

Pada berbagai kasus hemofilia, tidak terdapat riwayat keluarga dengan penyakit ini, dan sedikitnya $30 \%$ kasus hemofilia terjadi karena mutasi spontan (de novo). Hemofilia merupakan hasil dari mutasi pada gamet lakilaki normal, misalnya pada mutasi germ cell dari kakek akan memberikan gen hemofilia pada anak wanitanya sehingga cucu laki-lakinya bisa menderita hemofilia. Karakteristik Hemofilia A antara lain perdarahan yang banyak dalam berbagai jaringan dalam tubuh, termasuk hematom pada jaringan lunak dan hemartrosis yang menyebabkan hemartropati. Hemartrosis berulang merupakan karakteristik penyakit ini.

Pada aktivitas $\mathrm{f}$-VIII dan $\mathrm{f}-\mathrm{IX}>25 \%$ dari normal, hemofilia ditemukan karena perdarahan setelah trauma mayor atau saat tes laboratorium rutin sebelum pembedahan. Tes koagulasi pada umumnya hanya menunjukkan pemanjangan aPTT terisolasi, dengan waktu perdarahan dan hitung trombosit yang normal. Diagnosis dibuat setelah pemeriksaan aktivitas pembekuan $\mathrm{f}-\mathrm{VIII}$ dan $\mathrm{f}-\mathrm{IX}$ (5).

Berdasarkan data, 1-2\% hemofilia berat menyebabkan pseudotumor, yang bisa berasal dari jaringan lunak atau pada subperiosteal atau area intraosseus (1). Pseudotumor adalah kista berisi darah yang terjadi pada jaringan lunak atau tulang. Terbagi menjadi 3 tipe, yaitu simple cyst, yang berupa perlekatan tendon dalam fascia otot. Tipe kedua yaitu kista dalam jaringan lunak tetapi melibatkan pasokan vaskular pada perbatasan tulang dan periosteum, membentuk formasi kista dan resorpsi tulang. Tipe ketiga merupakan hasil perdarahan subperiosteal yang membagi periosteum dengan kortex tulang (2). Pseudotumor jarang terjadi namun merupakan komplikasi hemofilia yang berbahaya. Di RSSA, kasus pseudotumor hemofilia baru didapatkan 1 kasus dalam 4 tahun terakhir.

\section{KASUS}

Seorang laki-laki 27 tahun dikonsulkan ke bagian ilmu penyakit dalam. Dari anamnesis didapatkan keluhan bengkak pada paha kanan sejak 1 bulan terakhir. Keluhan bengkak terjadi tiba-tiba, merata dari pangkal paha sampai dengan lutut. Paha yang bengkak ini terasa nyeri, teraba panas, dan beberapa waktu sebelumnya berwarna kebiruan. Sebelumnya keluhan ini pernah juga dialami pasien, bergantian pada kaki kanan maupun kiri, sejak tahun 2002. Keluhan ini terakhir dirasakan pada bagian belakang lutut kiri tahun 2008. Pada belakang lutut kiri terjadi pembengkakan dan sempat pecah dengan mengeluarkan darah.

Riwayat perdarahan yang sulit berhenti dikeluhkan pasien sekitar 15 tahun yang lalu saat tangan kanannya luka. Perdarahan berhenti setelah 5 hari. Pasien juga mengeluhkan kadang lebam tanpa sebab di kedua tungkainya. Pasien sering mendapatkan transfusi darah, namun tidak mengetahui diagnosis penyakitnya. Sebulan sebelumnya pasien dirawat di bagian Bedah dengan keluhan bengkak paha kanan yang diduga suatu tumor. Pada anamnesis riwayat keluarga didapatkan kakak lakilaki penderita menderita keluhan yang sama, yaitu perdarahan yang sulit berhenti.

Pemeriksaan fisik menunjukkan kondisi pasien tampak sakit sedang, dengan tanda vital yang normal (tekanan darah 110/70 mmHg, nadi 72 kali per menit, dan visual analog scale (VAS) 2, pada ekstremitas didapatkan atrofi pada otot kaki kiri dan kontraktur pada lutut kiri. Pada kaki kanan didapatkan edema pada paha kanan, merata, tidak panas, tidak merah. Dikatakan bahwa pembengkakan ini berkurang dibandingkan saat dirawat di bagian Bedah sebulan sebelumnya.

Pemeriksaan laboratorium menunjukkan adanya pemanjangan aPTT 81, penurunan Faktor VIII (7\%, nilai normal $70-150 \%$ ), faktor IX 137\% (nilai normal 70-150\%) dan disimpulkan sebagai hemophilia A sedang (Tabel 1).

Tabel 1. Hasil pemeriksaan laboratorium

\begin{tabular}{lcr}
\hline Komponen & Hasil & Nilai normal \\
\hline Hb & 13,3 & $11,0-16,5 \mathrm{~g} / \mathrm{dl}$ \\
Lekosit & 7490 & $3.500-10^{4} / \mu \mathrm{L}$ \\
PCV & 39,8 & $35-50 \%$ \\
Trombosit & 303.000 & $15 \times 10^{4}-39 \times 10^{4} / \mu \mathrm{L}$ \\
Ureum & 19,4 & $10-50 \mathrm{mg} / \mathrm{dL}$ \\
Kreatinin & 0,66 & $0,7-1,5 \mathrm{mg} / \mathrm{dL}$ \\
Asam urat & 5,7 & $2-6 \mathrm{~g} / \mathrm{dL}$ \\
SGOT & 18 & $11-41 \mathrm{U} / \mathrm{L}$ \\
SGPT & 11 & $10-41 \mathrm{U} / \mathrm{L}$ \\
Faktor VIII & $\mathbf{7}$ & $70-150 \%$ \\
Faktor IX & $\mathbf{1 3 7}$ & $70-150 \%$ \\
APTT & $\mathbf{8 1}$ & $20-35 \mathrm{detik}$ \\
\hline
\end{tabular}

Gambaran radiologis femur kanan menunjukkan pembengkakan jaringan lunak. Hasil pemeriksaan magnetic resonance imaging (MRI) didapatkan massa intra muskular regio femur dekstra $1 / 3$ proksimal hingga $1 / 3$ tengah yang meliputi muskulus kompartemen anterior dan medial, melingkupi vaskular. Gambaran tersebut disertai hiperostosis os femur dekstra dicurigai ganas, kecurigaan hematoma sisi postero medial femur dekstra $1 / 3$ proksimal, massa intra muskular regio femur sinistra 
$1 / 3$ proksimal melibatkan kompartemen anterior. Berdasarkan gambaran tersebut disimpulkan suggestif maligna dengan kecurigaan rhabdomyosarcoma.

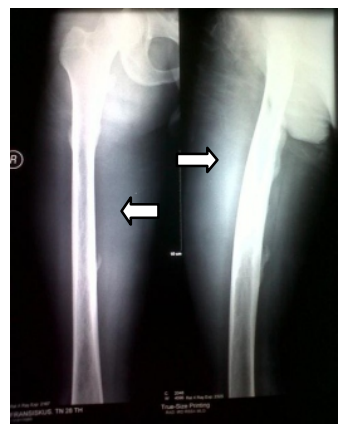

Gambar 1. Radiologis femur D
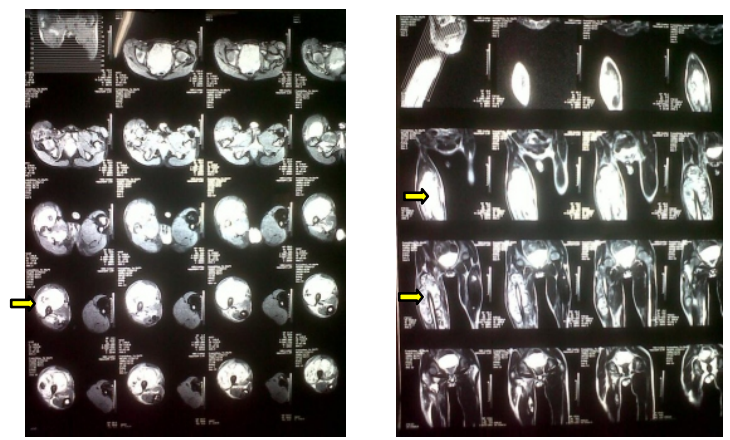

Gambar 2. MRI femur D/S

Hasil pemeriksaan fine needle aspiration biopsy (FNAB) dari laboratorium patologi anatomi pada massa di femur kanan menunjukkan bahwa sediaan hanya terdiri dari darah, jaringan nekrotik, dan sebaran longgar sel radang PMN dan MN.

\section{DISKUSI}

Hemofilia A lebih banyak terjadi (85\%) dibanding dengan Hemofilia B (5). Pada kasus hemofilia A biasanya didapatkan perdarahan yang berlangsung lama dari luka kecil yang disebabkan oleh kekurangan faktor pembekuan yang spesifik (1). Manifestasi yang paling sering terjadi adalah hemartrosis, baik karena trauma maupun muncul secara spontan. Perdarahan sendi ini terjadi sekitar $75 \%$ episode perdarahan berat pada hemofilia A. Hal yang paling sering membawa pasien dengan hemofilia berobat ke rumah sakit adalah ada.nya perdarahan yang sulit berhenti, dalam hitungan jam atau bahkan hari. Pada pemeriksaan laboratorium pasien hemofilia A didapatkan adanya penurunan faktor VIII atau IX dan pemanjangan aPTT.

Hemofilia A pada pasien ini baru terdiagnosa setelah 10 tahun dari gejala awal. Kecurigaan Hemofilia A bisa didasarkan pada adanya riwayat pembengkakan sendi berulang yang saat diaspirasi ternyata berisi darah, dan ditegakkan dengan pemeriksaan faktor VIII dan faktor IX. Pada saat dirawat pertama kali di Bagian Bedah, pemeriksaan laboratorium awal menunjukkan peningkatan aPTT dan penurunan faktor VIII. Dengan nilai faktor VIII 7\%, pasien ini masuk kategori hemofilia A ringan (5).

Pembengkakan pada paha yang terjadi pada pasien ini dapat terjadi karena hemartrosis (intra-articular bleeding) ataupun perdarahan intramuskular berulang. Perdarahan berulang ini dapat menyebabkan terjadinya pembengkakan kistik yang progresif dan disertai dengan keterlibatan tulang dari gambaran radiologisnya, dan disebut sebagai hemophilic pseudotumor. Hanya sekitar 1$2 \%$ pasien dengan hemofilia berat yang menunjukkan suatu pseudotumor hemofilia. Perdarahan yang tidak diterapi akan membentuk massa yang menyebabkan kompresi dan nekrosis struktur yang berdekatan. Patologi dari pseudotumor hemofilia pada tulang sebenarnya tidak diketahui dengan pasti (6). Mekanisme terbentuknya pseudotumor ini diduga karena adanya nekrosis karena tekanan pada tulang (destruksi tulang karena adanya hemartrosis), pembentukan tulang baru, dan komponen jaringan lunak yang terdiri dari hematom multipel dengan kosistensi seperti jelly (1). Dari literatur lain disebutkan bahwa penyebabnya dapat karena perdarahan jaringan lunak dan subperiosteal dengan nekrosis tulang yang diikuti dengan pembentukan tulang dan adanya perdarahan intraosseal yang kemudian diikuti oleh pembentukan kista dengan destruksi tulang dan terjadinya perdarahan berikutnya (6).

Pseudotumor hemofilia ini paling sering terjadi pada tulang panjang (femur, panggul, tibia, tulang tangan). Perdarahan intramuskular yang tidak hilang dan terjadi berulang akan menyebabkan terbentuknya kapsul dan kalsifikasi. Perdarahan berulang dengan pembentukan hematom dan hemartrosis merupakan manifestasi paling sering dari hemofilia. Otot yang paling sering terlibat adalah iliopsoas dan gastrocnemeus, dan sendi yang paling sering terkena adalah sendi lutut, angkle, siku, bahu dan panggul $(7,8)$.

Patogenesis pseudotumor berbeda menurut letak anatominya. Tulang tubular panjang adalah lokasi yang paling sering karena pada tulang ini lebih berisiko terkena trauma langsung, dan jika terjadi hematoma intramuskular berulang dan belum terselesaikan akan menyebabkan enkapsulasi dan kalsifikasi, dengan pembesaran massa yang progresif dan erosi tulang yang berdekatan (5). Dua pola klinis terbentuknya pseudotumor adalah proksimal dan distal. Pseudotumor proksimal terjadi pada proksimal kerangka, terutama di sekitar paha dan panggul; berawal pada jaringan lunak, mengikis tulang secara sekunder dari luar, dan berkembang perlahan selama bertahun-tahun. Pola ini terjadi pada orang dewasa dan tidak berespon dengan pengobatan konservatif. Pseudotumor distal terjadi pada distal pergelangan tangan dan pergelangan kaki, tampaknya sekunder karena perdarahan intraosseous, dan berkembang dengan cepat. Pola ini terlihat terutama pada anak dan dewasa muda; diduga karena trauma langsung. Perdarahan yang masuk pada tulang kecil, seperti calcaneus, talus dan tulang kecil kaki dianggap bertanggung jawab pada pseudotumor dan kista pada tulang-tulang ini. Pseudotumor dapat hilang setelah pemberian radiasi dosis rendah (9).

Penegakan diagnosis pseudotumor hemofilia adalah dengan menggunakan pencitraan radiologis, ultrasonografi, CT scan, MRI, dan pemeriksaan injeksi vaskular (7). Tanda yang paling penting dari gambaran radiologi adalah reaksi periosteal, formasi tulang baru, destruksi tulang yang disebabkan karena nekrosis tekanan, dan massa jaringan lunak dengan atau tanpa deposit kalsium (1). Reaksi periosteal yang terjadi pada pseudotumor hemofilia mungkin disebabkan oleh fenomena tekanan nekrosis dimana perdarahan yang berulang masuk ke dalam ruang subperiosteal yang 
tertutup atau area perdarahan intraosseusmenyebabkan tekanan yang cukup untuk menginduksi nekrosis tulang. Pada pasien ini, dari hasil MRI dapat disimpulkan terdapat massa dan sudah ada keterlibatan tulang. Hal ini mendukung suatu pseudotumor hemofilia (10). Lesi lain yang menjadi diagnosis banding dari pseudotumor hemofilia adalah fibrosarkoma, plasmacytoma, malignant fibrohistiocytoma, brown tumor, chondroma, giant cell tumor, dan kista hidatidosa (1). Dari kepustakaan juga disebutkan bahwa sebenarnya pemeriksaan dengan FNAB merupakan kontra indikasi dalam beberapa kasus karena dapat menyebabkan konsekuensi perdarahan. Namun pada kasus ini, hasil FNAB menyingkirkan diagnosis rhabdomiosarkoma yang dicurigai berdasarkan hasil kesimpulan MRI.

Tidak ada standar khusus penanganan pseudotumor hemofilia. Terapinya cukup sulit dan memerlukan pendekatan multimodalitas. Hal ini tergantung dari ukuran pseudotumor, letak pseudotumor dan ada inhibitor (6). Terapi yang dilakukan berupa terapi konservatif (immobilisasi, pemberian faktor VIII atau IX), pembedahan, evakuasi perkutaneus, dan radioterapi (9). Dalam beberapa jurnal disebutkan bahwa penanganan untuk pseudotumor hemofilia adalah dengan terapi konservatif, ada pula yang menyebutkan bahwa operasi memiliki keuntungan lebih dibanding dengan terapi substitusi berkepanjangan. Bila terjadi perdarahan pada sendi dan otot, dapat dilakukan metode "RICE" yaitu: istirahatkan anggota tubuh yang terjadi perdarahan (Rest), kompres bagian tubuh tersebut dan daerah sekitar dengan es atau bahan lain yang lembut dan beku/dingin (Ice), tekan dan ikat, sehingga bagian tubuh yang mengalami perdarahan tidak dapat bergerak. Gunakan perban elastis jangan terlalu keras (Compressed), letakkan bagian tubuh tersebut dalam posisi lebih tinggi dari posisi dada dan letakkan diatas benda yang lembut seperti bantal (Elevation) (11).

Penanganan lesi proksimal besar adalah konservatif. Imobilisasi dan pemberian faktor VIII pengganti dikatakan gagal mencegah perkembangan. Dengan penanganan

\section{DAFTAR PUSTAKA}

1. Valder Arruda and High KA. Coagulation Disorder. In: Longo DL (Ed). Harrison's Hematology 17th edition. China: The Mc Graw-Hill; 2012; pp. 235-245.

2. Pakala A, Thomas T, and Comp P. Hemophilic Pseudotumor: A Case Report and Review of Literature. International Journal of Clinical Medicine. 2012; 3: 229-233.

3. Kempton CL, Escobar MA, and Roberts HR. Hemophilia Care in The 21st Century. Clinical Advances in Hematology \& Oncology. 2004; 2(11): 733-740.

4. Van Ommeren JW, Mooren DW, Veth RP, Novakova IR, and van de Kaa CA. Pseudotumor Occurring in Hemophilia. Archieve of Orthopaedic Trauma Surgery. 2000; 120(7-8): 476-478.

5. Rodriguez-Merchan EC. Prevention of the Musculoskeletal Complications of Hemophilia. Advances in Preventive Medicine. 2012; 2012: 8.

6. Rijal L, Neogi DS, Ansari MT, Khan SA, and Yadav CS. Hemophilic Psuedotumor- is there a Role of Radiotherapy? Literature Review and a Case Report. tersebut dilaporkan terdapat regresi, tetapi tidak ada laporan mengenai penyembuhan yang sebenarnya, sehingga cepat atau lambat kekambuhan tidak bisa dihindari. Pseudotumor proksimal yang besar pada orang dewasa harus diangkat melalui pembedahan segera setelah terdiagnosis, kecuali ada alasan untuk menunda (9).

Terapi lainnya adalah dengan radioterapi. Dosis radiasi optimal untuk pseudotumor hemofilia tidak disebutkan dengan pasti. Disebutkan bahwa dosis 900 cGy tidak mengganggu pertumbuhan epifiseal dan dosis ini cukup untuk menyebab endarteritis atau pertumbuhan fibroblast. Operasi dilakukan apabila semua penanganan konservatif gagal atau didapatkan perkembangan yang signifikan dari pseudotumornya (12). Penilaian awal untuk pertimbangan operasi harus mencakup radiografi polos, ultrasonografi dan CT scan. Arteriografi harus dilakukan pada pseudotumor di tungkai untuk pertimbangan tindakan bedah yang memadai untuk lesi. Pada anak, operasi pengangkatan atau bahkan amputasi diindikasikan ketika manajemen konservatif gagal untuk mencegah progresifitas (9)

Pada pasien ini dilakukan terapi konservatif dengan immobilisasi dan pemberian faktor VIII. Hal ini dilakukan dengan pertimbangan bahwa pseudotumor yang terbentuk tidak terlalu besar dan dikatakan sudah mengecil dibanding sebulan sebelumnya. Faktor VIII diberikan hingga $25-50 \%$, diberikan dengan perhitungan unit yang dibutuhkan adalah berat badan $\mathrm{x}$ target faktor VIII $\times 0,5$ sehingga pasien mebutuhkan 1000 unit faktor VIII. Pada perkembangannya keluhan bengkak pada paha kanan berkurang dan kondisi klinisnya membaik.

Sebagai kesimpulan, pada kasus perdarahan yang spontan, berulang atau perdarahan tanpa sebab, terutama pada laki-laki perlu dipertimbangkan kemungkinan hemofilia. Jika muncul komplikasi muskuloskeletal, terutama pseudotumor, tindakan yang dilakukan adalah terapi konservatif dengan penggantian faktor VIII atau XI (sesuai jenis hemofilianya) dan tidak boleh dilakukan tindakan aspirasi atau biposi pada pseudotumor tersebut.

Nepal Medical College Journal. 2010; 12(3): 193-197

7. Koenigkam-Santos $\mathrm{M}$, Polezi $\mathrm{MB}$, Engel $\mathrm{EE}$, et al. Uncommon Presentations of Intraosseous Hemophilic Pseudotumor in Imaging Diagnosis. Radiologia Brasileira Journal. 2009; 42(3): 159-163.

8. Stafford JM, James TT, Allen AM, and Dixon LR. Hemophilic Pseudotumor: Radiologic-Pathologic Correlation. Radiographics. 2003; 23(4): 852-856.

9. Merchan REC. The Haemophilie Pseudotumour. International Orthopaedics. 1995; 19(4): 255-260.

10. Mahmud AA, Bashir Y, Taura MG, and Adamu LH. Haemophilic Pseudotumor: A Rare Pathological Entity Involving 5th Metacarpal and Associated Tissues. Scholars Journal of Applied Medical Sciences. 2015; 3(4B): 1707-1711

11. Kang JO, Cho YJ, Yoo MC, and Hong SE. Hemophilic Pseudotumor of the Ulna Treated with Low Dose Radiation therapy: A Case Report. Journal of Korean Medical Science. 2000; 15(5): 601-603.

12. Word Federation of Hemophilia. Guideline for Management of Hemophilia. 2nd edition. Montréal, Québec: Blackwell Publishing in Haemophilia; 2012. 